Illinois State University

ISU ReD: Research and eData

Theses and Dissertations

$11-4-2019$

\title{
Prominence of Slut Shaming Connected with Sexual Objectification: Boys Will Be Boys and Girls Will Be Sluts
}

Christina M. Whitaker

Illinois State University, cmgerie@ilstu.edu

Follow this and additional works at: https://ir.library.illinoisstate.edu/etd

Part of the Psychology Commons

\section{Recommended Citation}

Whitaker, Christina M., "Prominence of Slut Shaming Connected with Sexual Objectification: Boys Will Be Boys and Girls Will Be Sluts" (2019). Theses and Dissertations. 1191.

https://ir.library.illinoisstate.edu/etd/1191

This Thesis is brought to you for free and open access by ISU ReD: Research and eData. It has been accepted for inclusion in Theses and Dissertations by an authorized administrator of ISU ReD: Research and eData. For more information, please contact ISUReD@ilstu.edu. 


\title{
PROMINENCE OF SLUT SHAMING CONNECTED WITH SEXUAL OBJECTIFICATION: BOYS WILL BE BOYS AND GIRLS WILL BE SLUTS
}

\author{
Christina M. Whitaker
}

\section{Pages}

The primary purpose of this research was to develop a psychometric for slut shaming that would serve as a reliable and valid measure. The secondary purpose was to look at the relation between slut shaming and sexual objectification as it pertains to gender and race. Participants ( $n$ =202) were recruited using Amazon Mechanical Turk (MTurk) and asked to complete survey questions. Research analyses found the Slut Shaming Scale to be a reliable and valid measure without having to exclude any of the original items on the psychometric. Additional analyses showed that men reported victim blaming significantly more often than women, though there were not significant differences across race. Correlation analyses revealed a positive correlation between men's and women's slut shaming behaviors and their sexually objectifying experiences, a positive correlation between men's and women's slut shaming beliefs and experiences being the victim, a positive correlation between men's and women's slut shaming behaviors and their experiences being the victim, and a positive correlation between men's and women's victim blaming and experiences being the victim of slut shaming. Results also indicated that women experience sexual objectification more often than men. Limitations and future research directions are discussed.

KEYWORDS: Sexual objectification, slut shaming, the sexual double standard 
PROMINENCE OF SLUT SHAMING CONNECTED WITH SEXUAL OBJECTIFICATION:

BOYS WILL BE BOYS AND GIRLS WILL BE SLUTS

CHRISTINA M. WHITAKER

A Thesis Submitted in Partial Fulfillment of the Requirements for the Degree of

MASTER OF SCIENCE

Department of Psychology

ILLINOIS STATE UNIVERSITY 
C 2020 Christina M. Whitaker 


\section{PROMINENCE OF SLUT SHAMING CONNECTED WITH SEXUAL OBJECTIFICATION:}

BOYS WILL BE BOYS AND GIRLS WILL BE SLUTS

CHRISTINA M. WHITAKER

COMMITTEE MEMBERS:

Matthew Hesson-McInnis, Chair

Brea Banks

Corinne Zimmerman 


\section{CONTENTS}

Page

TABLES

iii

CHAPTER I: INTRODUCTION

CHAPTER II: LITERATURE REVIEW

$\begin{array}{ll}\text { Sexual Objectification } & 4\end{array}$

Slut Shaming and The Sexual Double Standard 7

The Current Study 11

Hypotheses 11

Research Questions $\quad 11$

CHAPTER III: METHODS 13

$\begin{array}{ll}\text { Participants } & 13\end{array}$

$\begin{array}{ll}\text { Measures } & 13\end{array}$

$\begin{array}{ll}\text { Procedure } & 15\end{array}$

CHAPTER IV: RESULTS 16

$\begin{array}{ll}\text { Descriptive Analyses } & 16\end{array}$

Hypothesis Testing $\quad 16$

$\begin{array}{ll}\text { CHAPTER V: DISCUSSION } & 27\end{array}$

$\begin{array}{ll}\text { Limitations } & 29\end{array}$

$\begin{array}{ll}\text { Implications } & 30\end{array}$

Future Research Directions 30

$\begin{array}{ll}\text { Conclusion } & 31\end{array}$ 
REFERENCES

APPENDIX: SCALES 


\section{TABLES}

Table

Page

1. Factor Loadings and Communalities for the Four Slut Shaming Subscales

2. Means (SDs) and sample-sizes for Slut Shaming Beliefs as a Function of Race and Gender Responses

3. Means (SDs) and sample-sizes for Slut Shaming Behaviors as a Function of Race and Gender Responses

4. Means (SDs) and sample-sizes for Slut Shaming Victim Blaming as a Function of Race and Gender Responses

5. Means (SDs) and sample-sizes for Slut Shaming Being the Victim as a Function of Race and Gender Responses

6. Correlations of Responses for Subscale of the Slut Shaming Scale 


\section{CHAPTER I: INTRODUCTION}

The first goal of the current research was to develop a measure for slut shaming and evaluate the psychometric properties of that new scale. The second goal was to examine the relation between sexual objectification (i.e., viewing people as depersonalized objects of desire) and slut shaming (i.e., stigmatizing women for engaging in sexual behavior). Specifically, the plan was to determine the degree to which gender and race impact participant experiences and engagement based on responses to measures of both sexual objectification and slut shaming.

Sexual objectification and slut shaming are important topics to understand. Although there have been several studies about sexual objectification, there has been little research on slut shaming. Slut shaming is a fairly new term and is often viewed as politically incorrect in the current U.S. culture. Researchers have studied elements of slut shaming using a more common term, the sexual double standard, defined as rules that apply to two people or two groups of people differently (Hamilton \& Armstrong, 2009), typically different rules for both men and women. The current usage of slut shaming, in contrast, focuses on judgments of women for engaging in sexual behavior (Summit, Kalmuss, DeAtley, \& Levack, 2016).

The term "slut shaming" can be discussed in terms of its roots in culture and religion. A study by Almazan and Bain (2015) discussed the concept of virginity and how it has been used to punish women and limit women's rights. We know from studies on the sexual double standard that in society men are expected to pursue sexual opportunities with a variety of sex partners, whereas women are expected to avoid sexual opportunities unless they are in the context of love, such as a committed relationship or marriage (Hamilton \& Armstrong, 2009). Other studies have shown the importance of this phenomenon in individuals' everyday lives. For example, Kohli (2016) discussed how female students are shamed through unwelcomed sexual comments, jokes, 
or gestures. These behaviors are a form of bullying, referred to as gendered bullying or sexualized bullying. This type of bullying has been associated with victims engaging in selfharm behaviors and in some cases attempting or completing suicide (Kohli, 2016). These findings together help demonstrate the importance of the concept of slut shaming because it is happening in individuals' everyday lives, as Kohli's results suggest $46 \%$ of girls and $22 \%$ of boys have reported experiencing these instances in person and more than $25 \%$ of girls and $13 \%$ of boys reported these experiences online.

Due to the frequency and severity of slut shaming (Kohli, 2016), research on slut shaming and how it can impact individuals is needed. In particular, it is important to understand whether and how such effects are experienced by women and men, and if the impact of slut shaming is different for people of color. Fasoli, Durante, Mari, Zogmaister, and Volpato (2017) found that there are gender differences when it comes to sexual objectification, and Watson, Marszalek, Dispenza, and Davids (2015) found that there are sexual objectification differences between White and African American women. Research on objectification may provide insight into how and why slut shaming occurs, as well as who is perpetrating slut shaming versus who is being slut shamed and which types of behaviors prompt perpetrators to engage in slut shaming. Examining the relation between slut shaming behaviors and a tendency to engage in sexual objectification may provide insight into ways to reduce both behaviors.

This study has important implications for the research community. We know from research by Kholi (2016) that sexualized bullying is happening school wide. Identifying these relations is a first step toward helping us characterize the scope of the problem of slut shaming and hopefully reveal potential intervention strategies that could be used to help decrease or even stop sexualized bullying, slut shaming, and sexual objectification. 
Compelling research to illuminate these relations, however, is not possible without a psychometrically sound measure of slut shaming, and evidence of reliability and validity are important aspects of all measures. Currently, there is no reliable and valid measure for slut shaming. My primary goal, as stated above, is to find preliminary evidence of reliability and validity for the Slut Shaming Scale developed for the current research. 


\section{CHAPTER II: LITERATURE REVIEW}

\section{Sexual Objectification}

Sexual objectification is defined as viewing individuals or their bodies simply as objects, as separate from themselves or their identity (Fasoli, Durante, Mari, Zogmaister, \& Volpato, 2017). Objectification can occur in both personal encounters as well as in the media (Fasoli et al., 2017). Fasoli and colleagues (2017) discuss that both men and women are the targets of objectification that occurs in mass media; however, women are objectified more frequently. The media, most notably television commercials and magazines, have promoted sexual objectification in advertisements that frequently display individuals dressed in minimal clothing engaging in everyday activities such as eating a hamburger, washing a car, or modeling cologne or perfume. In some cases, only specific body parts are used to advertise various kinds of merchandise (Fasoli et al., 2017).

Fasoli and colleagues (2017) examined how sexualization influences sexual objectification, or perceptions of individuals as sexual objects. These researchers investigated different types of sexualization (e.g., models in regular clothing, merely revealing clothing, and sexualized revealing clothing) to determine their contribution to different perceptions of women and men as targets of sexual objectification. Through an online survey, Fasoli and colleagues (2017) exposed participants to photos of women and men in non-revealing clothing (i.e., nonrevealing dress, or blouse and jeans), merely revealing clothing (i.e., swimwear or underwear with a neutral pose), and sexualized revealing clothing (i.e., underwear with a sexual pose and facial expression). Measuring sexual objectification through a scale that the researchers created as well as measuring perceptions of competence (i.e., how well a person can do something) and sexiness through the "Ambivalent Sexism Inventory" (Glick \& Fiske, 1996), Fasoli and 
colleagues (2017) found that as sexualization increased in the photos, perceptions of the individual as a target of sexual objectification also increased. The results show that perceptions of women and men being viewed as sexual objects happen similarly. As photos became more sexualized, participants' sexual objectivity scores increased for photos of both men and women. Participants also judged both groups as more incompetent as their images became more sexualized. In other words, participants judged men and women as more incompetent as they became sexier in the photos.

Interestingly, the Fasoli and colleagues (2017) final hypothesis was not supported; participants rated the images of the female models as sexier as they went from non-revealing clothing to merely revealing clothing to sexualized revealing clothing. In contrast, men were rated as equally sexy in all three types of clothing. These results indicate that both men and women can be sexually objectified and that this objectification has an impact on the way those individuals are perceived. Additionally, men can be viewed as "sexy" no matter how they are dressed, but how much women are perceived as "sexy" depends on how they are dressed.

Mikorski and Szymanski (2016) studied the sexual objectification of women by men based on masculine norms, peer group, pornography and Facebook use. One of the scales used was the "Conformity to Masculine Norms Inventory" (Parent \& Moradi, 2011). The research was conducted via online survey administration, and participants consisted of heterosexual men. Three dimensions of masculine roles from the "Masculine Roles Inventory" were examined, including the playboy (e.g., "If I could I would frequently change sexual partners"), power over women (e.g., "Things tend to better when men are in charge"), and violence (e.g., "Sometimes violent action is necessary") themes. Mikorski and Szymanski (2016) found that the three dimensions significantly related to an increased sexual objectification of women. Additionally, 
the playboy and power over women dimensions were related to making an increased number of unwanted sexual advances toward women.

The realities of sexual objectification extend beyond the differences between women and men, as race also plays an important role. As part of one study, Watson et al. (2015) examined differences in the way White and African American women experience sexual objectification, specifically surrounding feelings about their physical safety, anxiety, and their overall psychological distress. Participants in the study completed online surveys that included the "Interpersonal Sexual Objectification Scale" (e.g., "How often have you been whistled at while walking down the street?"; Kozee et al., 2007), "Fear of Rape Scale” (e.g., "How safe do you feel in your apartment/house when you are by yourself?"; Senn \& Dzinas, 1996), "Fear of Crime Scale" (e.g., "Please rate your fear of having someone break into your house while you are away"; Ferraro, 1995), and the "Depression, Anxiety, and Stress Scales" (e.g., "I feel I have a lot of nervous energy"; Lovibond \& Lovibond, 1995). Watson and colleagues, (2015) found that the relation between perceived risk of crime and sexual objectification was comparable for both groups of women, even though African American women reported more experiences of sexual objectification and greater fear of crime than White participants. When fear of crime was taken into account, it controlled for the relation between objectification and psychological distress for the group of African American women but not for the group of White women. For White women, when fear of crime was taken into account, the relation between objectification and fear of rape was controlled for. In sum, the results showed that women's experience with sexual objectification is related to their sense of safety as well as showing that there are differences in sexual objectification based on race. 


\section{Slut Shaming and The Sexual Double Standard}

Slut shaming is a term used to refer to the stigmatizing of women or men for engaging in presumed sexual activity (Pickel \& Gentry, 2016). It is far more common, however, for women to be the targets of slut shaming due to the sexual double standard, which Hamilton and Armstrong (2009) discuss as, “...men are expected to desire and pursue sexual opportunities regardless of context, women are expected to avoid casual sex-having sex only when in relationships and in love" (p. 593). Slut shaming can be thought of as qualitatively different from the sexual double standard with respect to the idea that in current U.S. culture, slut shaming is often engaged in by women who attempt to police or regulate the behavior of other women and girls (e.g., Ringrose \& Renode, 2012). Slut shaming can be based on actual sexual behavior or perceived sexual behavior (e.g., gossip; Mishna et al., 2018). Beyond the idea of the sexual double standard, slut shaming can be considered a form of bullying or cyberbullying (Kholi, 2016). When it comes to slut shaming in particular, we can see the sexual double standard at play. Women can experience frequent teasing or bullying more often than men based on their presumed or actual sexual behavior (Fasoli et al., 2017). Although women may be slut shamed for sexual behavior, responses to the same behavior in men is often much different. It is also common for heterosexual men to be viewed as cool, favored, and trendy when participating in these same sexual behaviors rather than bullied.

As part of a qualitative study conducted by Hamilton and Armstrong (2009) that examined the entirety of college women's sexual and romantic experiences, one participant stated, "Guys can have sex with all the girls, and it makes them more of a man, but if a girl does then all of a sudden she's a ho, and she's not as quality of a person" (p. 598). Another participant from the same study said, "Guys, they can go around and have sex with a number of girls and 
they're not called anything" (p. 598). Other participants in their study discussed how easy it is for women to obtain a negative reputation from "hooking up" with multiple men, when the same is not true for men who engage in sexual activity with multiple women.

Although slut shaming is prominent in colleges (Hamilton \& Armstrong, 2009), slut shaming also has a significant impact on students in middle school and high school. School environments seem to encourage slut shaming with sexual education curriculum and dress codes that teach male and female students that girls need to cover themselves up (Kohli, 2016). Female students are shamed, which is a form of gendered or sexualized bullying. As a result of the shaming, victims may engage in self-harm behavior and even attempt or complete suicide (Kohli, 2016).

Studies have found that students who experience bullying are more likely to have academic problems and physical health issues, including PTSD, anxiety, depression, suicidal ideation, and more. For example, Pickel and Gentry (2016) examined slut shaming by randomly assigning college participants to listen to one of two different recordings of a victim of bullying and the accused defendant of bullying through social media. Researchers manipulated the level of harm the victim experienced (i.e., low or high) and self-presentation in the victim's Facebook post, which was either revealing (i.e., cleavage revealing crop top and a short/tight skirt drinking from a shot glass) or casual (i.e., a photo uploaded of the victim at a sports event in a t-shirt and jeans, drinking a soda). Participants were brought into a lab and told to act as participants of a high school disciplinary committee and were asked to choose a verdict for the defendant, provide a sentence, and to rate the seriousness of the case. Participants gave guilty verdicts in both selfpresentation groups. The participants rated the seriousness of the case and the length of sentencing higher in both instances where harm was high. They rated the seriousness of the case 
and the sentencing lower in the condition where the student self-presented in a revealing manner on Facebook prior to the bullying event. Regardless of the level of harm experienced by the victim, participants rated the case as less serious and determined that less punishment was deserved when the victim posted a revealing photo on social media. Though the victim had not engaged in sexual behavior, the revealing photo was enough to encourage participants to feel that the victim was slightly more deserving of the bullying and the defendant less deserving of a punishment.

Vaillancourt and Sharma (2011) examined how women react to an unknown, attractive woman. Researchers exposed participants to an attractive woman who was wearing (a) conservative clothing (i.e., pants and a t-shirt with her hair up), or (b) revealing clothing (i.e., a low-cut shirt, knee-high boots, with her hair down). Attractiveness was determined in a pilot study by 20 undergraduate women who were believed to have understood presumed characteristics of attractiveness. Participants were asked to look at the images. Coders rated participants' expressions to determine if the participant reacted in a "bitchy" manner toward the images. Researchers defined bitchy as negative facial expressions, dismissive/avoidant behavior, "death stares," body posture, mocking, sarcastic tone of voice, and fake smiles. In the conservative clothing condition, only $10 \%$ of participants were coded as reacting in a bitchy manner. In the revealing clothing condition, $74 \%$ of participants were coded as acting bitchy. In a second study, the two clothing conditions remained the same and a third condition was added where the woman was wearing revealing clothing (i.e., a low-cut shirt, skirt, knee high boots, with her hair down) but modified to look as if she weighed more. Participants reported being less likely to be friends with the sexy-thin or sexy-fat confederate compared to the conservatively dressed confederate. As in the first study, female participants were more likely to react in a 
bitchy manner toward women who were dressed revealing rather than those dressed conservatively. However, weight did not appear to have an impact on the bitchiness of the participant when the confederate was dressed in a revealing manner.

As mentioned earlier the sexual double standard can be defined as rules about acceptable and unacceptable sexual behavior that apply differently to two different people or two different groups (Crawford \& Popp, 2003). Most commonly, the sexual double standard refers to different expectations for men and women. Soller and Haynie (2017) evaluated the sexual double standard in schools and how it impacts the sexual behavior of adolescents. Researchers assigned a level of the sexual double standard to the school based on the differential ratings of boys versus girls with respect to the statement, "If you had sexual intercourse, your friends would respect you more" (Soller \& Haynie, 2017, p. 709). Soller and Haynie (2017) hypothesized that the level of the sexual double standard within schools would have an impact on the number of sexual partners that male and female adolescents within the school environment have had. During the first wave of the study when the participants were age 15 , the researchers found that boys experienced more social benefits (e.g., respect from friends) based on how much sexual intercourse they reported, which was not the case for girls. These data were evidence of the sexual double standard within all but one of the 75 schools in the study. As the level of the sexual double standard increased, so did the number of sexual partners boys had within the school, which was not the case for girls. Hamilton and Armstrong (2009) also examined the sexual double standard and how it related to casual sexual activity on college campuses, also known as "hooking up." The researchers conducted an ethnography and longitudinal interviews with college women. Hamilton and Armstrong (2009) found that the sexual double standard, which has been strongly reinforced on college campuses, is a key part of the disrespect experienced by women who are in 
relationships and the powerlessness of women in relationships. These researchers suggest that the presence of the sexual double standard only reinforces male dominance across social norms.

\section{The Current Study}

The current study has two goals. The primary goal is to find evidence for the reliability and validity of the "Slut Shaming Scale" created for this study. The scale was created to assess attitudes about sexual behaviors and actual engagement in behaviors that can be designated as slut shaming.

The second goal is to conduct preliminary research on the relation between sexual attitudes (using the "Brief Sexual Attitudes Scale"; Hendrick, Hendrick \& Reich, 2006), sexual objectification (using the "Interpersonal Sexual Objectification Scale"; Kozee et al., 2007), and slut shaming. Very few studies in the reviewed research made comparisons between individuals of different races.

Based on the review of the literature the following set of hypotheses are proposed:

\section{Hypotheses}

H1: There will be sufficient evidence of reliability (using Cronbach's alpha) to warrant further investigation with the proposed Slut Shaming Scale measure.

$\mathrm{H} 2$ : There will be sufficient preliminary evidence of validity (using a factor analysis) to warrant further investigation with the proposed Slut Shaming Scale measure.

\section{Research Questions}

RQ1: Do women self-report experiencing slut shaming more often than men?

RQ2: Do women self-report engaging in slut shaming more often than men?

RQ3: Do differences exist in how women of color experience slut shaming compared to White women? 
RQ4: Are responses based on gender differences consistent across race on the Slut Shaming Scale?

RQ5: Will there be a positive correlation between how often women stigmatize others for sexual behavior and how often women experience sexual objectification?

RQ6: Do women experience sexual objectifying actions aimed towards them more often than men? 


\section{CHAPTER III: METHODS}

\section{Participants}

There were a total of 266 participants from the US recruited to participate in the study. Age limits were restricted to men and women over the age of 18 based on MTurk requirements. A total of 34 participants failed attention check questions and another 30 participants dropped out, leaving a total of 202 participants who successfully completed the study. Of these, 79.7\% self-identified as White/European American $(n=161), 7.9 \%$ identified as Black/African American $(n=16)$, five percent identified as Asian $(n=10)$, three percent identified as MultiEthnical/Multi-Racial $(n=6)$, three percent identified as Latinx/Hispanic $(n=6), .5 \%$ identified as American Indian/Alaskan Native $(n=1), .5 \%$ identified as Other $(n=1)$, and $.5 \%$ responses prefer not to answer $(n=1)$. Fifty percent identified as female $(n=101), 47.5 \%$ identified as male $(\mathrm{n}=96)$, and one percent identified as non-binary $(n=2)$. The remaining participants identified as transgender $(n=1)$, gender-fluid $(n=1)$, or responded that they prefer not to answer $(n=1)$. When disclosing sexual orientation, $78.2 \%$ identified as heterosexual $(n=158), 14.9 \%$ identified as bisexual ( $n=30), 2.5 \%$ identified as homosexual-lesbian $(n=5), 2$ percent identified as homosexual-gay $(\mathrm{n}=4), 1$ percent identified as pansexual $(n=2)$, and $.5 \%$ identified as asexual $(n=1$.) Participant's ages ranged from 18 to $72(M=36.87, S D=11.45)$.

\section{Measures}

The "Slut Shaming Scale" is a 26-item questionnaire that the researcher created (see Appendix), which consists of four subscales: (a) beliefs, (b) behaviors, (c) victim blaming, and (d) being the victim. The first part of the scale was designed to measure beliefs and attitudes about slut shaming using a seven-point scale from "strongly disagree" to "strongly agree" (e.g., "I think women are sluts for dressing in revealing ways"). The second part of the scale was 
designed to address the extent to which the participant engages in actual slut shaming behaviors using a seven-point scale from "zero" times within the past month to " 25 or more" times within the past the months (e.g., "On average, how many times within a month do you call a woman a slut"). The third part of the scale was designed to measure to the degree to which victim blaming is part of participant attitudes, and uses a seven-point scale from "strongly disagree" to "strongly agree" (e.g., "I feel that a women who dresses in a revealing or provocative way is at least partially responsible if she is sexually harassed or sexually assaulted"). Finally, the fourth part of scale measures the frequency with which the participant has experienced being the victim of slut shaming on a seven-point scale from "zero" times within the past month to " 25 or more" times within the past month (e.g., "On average, how many times within the past month have you have been called a 'slut' in person because of your sexual history").

The "Brief Sexual Attitudes Scale" (Hendrick, Hendrick, \& Reich, 2006) is a 23-item measure that uses a five-point Likert scale to assess individuals' beliefs about sexual behaviors. This measure is a shortened version of the original 43-item "Sexual Attitudes Scale", which has strong reliability across subscales. The four subscales include (a) Permissiveness (e.g., "I do not need to be committed to a person to have sex with him/her"); (b) Birth Control (e.g., "birth control is part of responsible sexuality"); (c) Communion (e.g., "sex is the closest form of communication between two people"); and (d) Instrumentality (e.g., "sex is primarily a bodily function, like eating"). Reported alpha levels for each subscale are acceptable, ranging from .77 to .95 (Hendrick et al., 2006). For the purpose of this study we utilized a seven-point scale from "strongly disagree" to "strongly agree" to keep the scale consistent across measures.

The "Interpersonal Sexual Objectification Scale" (Kozee et al., 2007) is a 15-item scale that measures the extent to which individuals have personally experienced sexual objectification 
(e.g., "how often have you been whistled at while walking down the street?" or "how often have you been touched or fondled against your will?"). Participants respond on a six-point Likert scale. This scale was tested in a pilot study that found the reliability to be strong $(\alpha=.93$, Kozee et al., 2007). For the purposes of this study, participants responded on a seven-point scale from "never" to "all of the time".

\section{Procedure}

The surveys were administered via the online survey tool Qualtrics to consenting participants through Amazon Mechanical Turk (MTurk), which is an amazon website that allows researchers to pay small sums to participants who consent to participate in their research. A total of 202 participants received $\$ 0.20$ for completing the study. MTurk allows researchers to choose age limits as well as participant limits. Specific human intelligence task (HIT) experience and completion rates were set to at least 50 previous HITs and a completion rate of those previous HITs to be at least $80 \%$. 


\section{CHAPTER IV: RESULTS}

\section{Descriptive Analyses}

Descriptive statistics were collected and means, as well as standard deviations, are reported for all survey measures. Means, standard deviations, and correlations are reported below and are also reported with respect to gender and race/ethnicity. Analyses are described below and paired with their respective hypothesis or research questions.

\section{Hypothesis Testing}

My first and second hypotheses relate to evaluating evidence of the psychometric properties of the Slut Shaming Scale. For the first hypothesis, I conducted an internal consistency examination of reliability. The beliefs subscale consisted of 14 items $(\alpha=.94)$; the behaviors subscale consisted of four items $(\alpha=.91)$; the victim blaming subscale consisted of four items $(\alpha=.88)$; and the being the victim subscale consisted of four items $(\alpha=.97)$. The Cronbach's alpha was also calculated for all four subscales together, consisting of a total of 26 items $(\alpha=$ .95). Thus, the slut shaming scale and all four subscales had Cronbach's alphas ranging in the good to excellent range, indicating strong reliability for the Slut Shaming Scale. None of the items were excluded.

For the second hypothesis, I conducted an exploratory factor analyses to establish factorial validity. I extracted one factor using Principle Axis Factoring. The analysis indicates that the Slut Shaming Scale can be well represented by a single factor (see Table 1 for factor loadings and communalities), supporting the factorial validity of this measure. 
Table 1

Factor Loadings and Communalities for the Four Slut Shaming Subscales

\begin{tabular}{|c|c|c|c|c|}
\hline Slut Shaming Beliefs & $\begin{array}{l}\text { Factor } \\
\text { Loading }\end{array}$ & $\begin{array}{l}\text { Communality } \\
\text { Estimate }\end{array}$ & $\begin{array}{l}\text { Corrected } \\
\text { Item Total } \\
\text { Correlation }\end{array}$ & $\begin{array}{l}\text { Cronbach's } \\
\text { Alpha if Item } \\
\text { Deleted }\end{array}$ \\
\hline $\begin{array}{l}\text { I think women are "sluts" for } \\
\text { dressing is revealing ways (e.g., } \\
\text { short shorts/skirts, low cut blouses } \\
\text { or tank tops, belly shirts). }\end{array}$ & .773 & .598 & .733 & .938 \\
\hline $\begin{array}{l}\text { I think men are "sluts" for dressing } \\
\text { in revealing ways (e.g., wearing V- } \\
\text { neck shirts, no shirts at all, or } \\
\text { wearing speedos instead of swim } \\
\text { trunks). }\end{array}$ & .758 & .575 & .720 & .938 \\
\hline $\begin{array}{l}\text { I consider women "sluts" based on } \\
\text { their use of contraceptives (e.g., } \\
\text { birth control, condoms). }\end{array}$ & .709 & .503 & .654 & .940 \\
\hline $\begin{array}{l}\text { I consider men "sluts" based on } \\
\text { their use of contraceptives (e.g., } \\
\text { condoms). }\end{array}$ & .649 & .422 & .594 & .941 \\
\hline $\begin{array}{l}\text { I consider women "sluts" based on } \\
\text { the number of sexual partners they } \\
\text { have had. }\end{array}$ & .734 & .538 & .740 & .937 \\
\hline $\begin{array}{l}\text { I consider men "sluts" based on } \\
\text { the number of sexual partners they } \\
\text { have had. }\end{array}$ & .676 & .457 & .683 & .939 \\
\hline $\begin{array}{l}\text { I consider women "sluts" for } \\
\text { engaging in premarital sex. }\end{array}$ & .800 & .639 & .752 & .937 \\
\hline $\begin{array}{l}\text { I consider men "sluts" for } \\
\text { engaging in premarital sex. }\end{array}$ & .764 & .583 & .714 & .938 \\
\hline $\begin{array}{l}\text { I consider women who engage in } \\
\text { stripping to be "sluts". }\end{array}$ & .803 & .644 & .801 & .936 \\
\hline $\begin{array}{l}\text { I consider men who engage in } \\
\text { stripping to be "sluts". }\end{array}$ & .799 & .639 & .797 & .936 \\
\hline
\end{tabular}




\begin{tabular}{|c|c|c|c|c|}
\hline Slut Shaming Beliefs & $\begin{array}{l}\text { Factor } \\
\text { Loading }\end{array}$ & $\begin{array}{l}\text { Communality } \\
\text { Estimate }\end{array}$ & $\begin{array}{l}\text { Corrected } \\
\text { Item Total } \\
\text { Correlation }\end{array}$ & $\begin{array}{l}\text { Cronbach's } \\
\text { Alpha if Item } \\
\text { Deleted }\end{array}$ \\
\hline $\begin{array}{l}\text { I consider women who engage in } \\
\text { prostitution to be "sluts". }\end{array}$ & .652 & .425 & .674 & .940 \\
\hline $\begin{array}{l}\text { I consider men who engage in } \\
\text { prostitution to be "sluts". }\end{array}$ & .648 & .420 & .671 & .940 \\
\hline $\begin{array}{l}\text { If a woman has sexual practices } \\
\text { that are different from my own } \\
\text { (e.g., masturbation, premarital sex, } \\
\text { experimentation with same-sex } \\
\text { partners, experimentation with } \\
\text { dominance and submission), I } \\
\text { would consider her to be a "slut". }\end{array}$ & .840 & .705 & .785 & .936 \\
\hline $\begin{array}{l}\text { If a man has sexual practices that } \\
\text { are different from my own (e.g., } \\
\text { masturbation, premarital sex, } \\
\text { experimentation with same-sex } \\
\text { partners, experimentation with } \\
\text { dominance and submission), I } \\
\text { would consider him to be a "slut". }\end{array}$ & .834 & .696 & .781 & .936 \\
\hline $\begin{array}{l}\text { Slut Shaming Behaviors } \\
\text { On average, how many times } \\
\text { within a month do you call a } \\
\text { woman a "slut" (e.g., to friends, } \\
\text { gossip) behind her back, based on } \\
\text { her sexual practices? }\end{array}$ & .792 & .628 & .757 & .895 \\
\hline $\begin{array}{l}\text { On average, how many times } \\
\text { within a month do you call a man a } \\
\text { "slut" (e.g., to friends, gossip) } \\
\text { behind his back, based on his } \\
\text { sexual practices? }\end{array}$ & .787 & .620 & .751 & .898 \\
\hline $\begin{array}{l}\text { On average, how many times } \\
\text { within a month have you directly } \\
\text { called a woman a "slut" (to their } \\
\text { face, online) based on her sexual } \\
\text { practices? }\end{array}$ & .956 & .914 & .882 & .858 \\
\hline $\begin{array}{l}\text { On average, how many times } \\
\text { within a month have you directly }\end{array}$ & .873 & .763 & .808 & .875 \\
\hline
\end{tabular}




\begin{tabular}{lllll}
\hline Slut Shaming Beliefs & Factor & Communality & Corrected & Cronbach's \\
& Loading & Estimate & $\begin{array}{l}\text { Item Total } \\
\text { Correlation }\end{array}$ & $\begin{array}{l}\text { Alpha if Item } \\
\text { Deleted }\end{array}$ \\
\hline
\end{tabular}

called a man a "slut" (to their face, online) based on his sexual

practices?

\section{Victim Blaming}

I feel that a woman who dresses in

a revealing or provocative way is at least partially responsible if she is sexually harassed or sexually assaulted.

I feel that a man who dresses in a revealing or provocative way is at least partially responsible if he is sexually harassed or sexually assaulted.

I feel that if a woman takes a nude .829 .688 blame if that photo gets distributed to people other than the intended recipient.

I feel that if a man takes a nude

photo of himself, only he is to blame if that photo gets distributed to people other than the intended recipient.

\section{Being the Victim}

On average, how many times

On average, how many times 


\begin{tabular}{lllll}
\hline Slut Shaming Beliefs & $\begin{array}{l}\text { Factor } \\
\text { Loading }\end{array}$ & $\begin{array}{l}\text { Communality } \\
\text { Estimate }\end{array}$ & $\begin{array}{l}\text { Corrected } \\
\text { Item Total } \\
\text { Correlation }\end{array}$ & $\begin{array}{l}\text { Cronbach's } \\
\text { Alpha if Item } \\
\text { Deleted }\end{array}$ \\
\hline $\begin{array}{l}\text { within the past month have you } \\
\text { been called a "slut" in person } \\
\text { because someone made } \\
\text { assumptions about your sexual } \\
\text { experience or sexual history? }\end{array}$ & & & & \\
& & & & \\
$\begin{array}{l}\text { On average, how many times } \\
\text { within the past month have you } \\
\text { been called a "slut" online because } \\
\text { someone made } \text { assumptions about } \\
\text { your sexual experience or sexual } \\
\text { history? }\end{array}$ & .965 & .931 & .944 & .950 \\
\hline
\end{tabular}

For the first research question (i.e., Do women self-report experiencing slut shaming more often than men?), I conducted an independent samples $t$-test on the responses from the being the victim subscale. The scores for the 96 male participants $(M=2.33, S D=0.78)$ and the 101 female participants $(M=2.23, S D=0.68)$ were not significantly different with respect to being the victim of slut shaming experiences, $t(195)=0.94, p=.076, d=0.137$.

For the second research question (i.e., Do women self-report engaging in slut shaming more often than men?), I conducted an independent samples $t$-test on the responses from the beliefs, behaviors, and victim blaming subscales. For the beliefs subscale, there was not a significant difference between men's $(M=3.00, S D=1.20)$ and women's responses $(M=2.65$, $S D=1.27), t(195)=1.98, p=314, d=0.283$. For the behaviors subscale, there was a marginally significant difference between male $(M=1.38, S D=0.81, n=96)$ and female participants $(M=$ $1.25, S D=0.68, n=101), t(195)=1.20, p=.059, d=0.174$. On the victim blaming subscale, male participants scored significantly higher $(M=3.26, S D=1.22, n=96)$ than female participants $(M$ $=2.99, S D=1.41, n=101), t(195)=1.47, p=.041, d=0.205$. 
For the third research question (i.e., Do differences exist in how women of color experience slut shaming compared to White women?), I conducted a multivariate analysis of variance (MANOVA). The responses of 79 White/European American women, 9 Black/African American women, and 13 non-Black/African American women of color, did not demonstrate significant differences, Wilks' $\Lambda=.88, F(8,190)=1.56, p=.138$. See Tables 2 through 5 for the marginal means and standard deviations of women of color.

For the fourth research question (i.e., Are responses based on gender differences consistent across race on the Slut Shaming Scale?), I conducted a two-way MANOVA. There was a significant main effect of gender, Wilks' $\Lambda=.86, F(16,575)=1.79, p=.029$, but no main effect for race, Wilks' $\Lambda=.94, F(8,376)=1.38, p=.205$. The participant responses did not demonstrate a significant interaction between gender and race, Wilks' $\Lambda=.97, F(8,376)=.60, p$ $=.776$. Tables 2 to 5 provides the means and standard deviation on the four subscales broken down by gender and race. 
Table 2

Means (SDs) and sample-sizes for Slut Shaming Beliefs as a Function of Race and Gender Responses

\begin{tabular}{|c|c|c|c|c|c|c|}
\hline Race & Male & Female & Transgender & Non Binary & Gender Fluid & Total \\
\hline $\begin{array}{l}\text { White/Europ } \\
\text { ean } \\
\text { American }\end{array}$ & $\begin{array}{l}\mathrm{M}=3.06(1.23) \\
\mathrm{n}=79\end{array}$ & $\begin{array}{l}\mathrm{M}=2.73(1.30) \\
\mathrm{n}=79\end{array}$ & - & $\begin{array}{l}M=1.73(0.66) \\
n=2\end{array}$ & $\begin{array}{l}M=1.40(0.00) \\
n=1\end{array}$ & $\begin{aligned} M & =2.87(1.29) \\
n & =161\end{aligned}$ \\
\hline $\begin{array}{l}\text { Black/Africa } \\
\text { n American }\end{array}$ & $\begin{array}{l}\mathrm{M}=3.30(0.55) \\
\mathrm{n}=7\end{array}$ & $\begin{array}{l}\mathrm{M}=2.21(1.28) \\
\mathrm{n}=9\end{array}$ & - & - & - & $\begin{array}{l}M=2.69(1.14) \\
n=16\end{array}$ \\
\hline $\begin{array}{l}\text { Other } \\
\text { People of } \\
\text { Color }\end{array}$ & $\begin{array}{l}\mathrm{M}=2.32(0.95) \\
\mathrm{n}=9\end{array}$ & $\begin{array}{l}M=2.45(1.06) \\
n=13\end{array}$ & $\begin{array}{l}M=2.93(0.00) \\
n=1\end{array}$ & - & - & $\begin{array}{l}M=2.42(0.98) \\
n=23\end{array}$ \\
\hline Total & $\begin{array}{l}M=3.01(1.21) \\
n=95\end{array}$ & $\begin{array}{l}M=2.65(1.27) \\
n=101\end{array}$ & $\begin{array}{l}M=2.93(0.00) \\
n=1\end{array}$ & $\begin{array}{l}M=1.73(0.66) \\
n=2\end{array}$ & $\begin{array}{l}M=1.40(0.00) \\
n=1\end{array}$ & $\begin{array}{l}M=2.80(1.25) \\
n=200\end{array}$ \\
\hline
\end{tabular}

Table 3

N Means (SDs) and sample-sizes for Slut Shaming Behaviors as a Function of Race and Gender Responses

\begin{tabular}{|c|c|c|c|c|c|c|}
\hline Race & Male & Female & Transgender & Non Binary & Gender Fluid & Total \\
\hline $\begin{array}{l}\text { White/Euro } \\
\text { pean } \\
\text { American }\end{array}$ & $\begin{array}{l}M=1.37(0.77) \\
n=79\end{array}$ & $\begin{array}{l}M=1.25(0.67) \\
n=79\end{array}$ & - & $\begin{array}{l}M=1.00(0.00) \\
n=2\end{array}$ & $\begin{array}{l}M=1.25(0.00) \\
n=1\end{array}$ & $\begin{array}{l}M=1.31(0.72) \\
n=161\end{array}$ \\
\hline $\begin{array}{l}\text { Black/Afric } \\
\text { an America }\end{array}$ & $\begin{array}{l}M=1.57(1.20) \\
n=7\end{array}$ & $\begin{array}{l}M=1.58(1.03) \\
n=9\end{array}$ & - & - & - & $\begin{array}{l}M=1.58(1.07) \\
n=16\end{array}$ \\
\hline $\begin{array}{l}\text { Other } \\
\text { People of } \\
\text { Color }\end{array}$ & $\begin{array}{l}M=1.36(0.99) \\
n=9\end{array}$ & $\begin{array}{l}M=1.08(0.21) \\
n=13\end{array}$ & $\begin{array}{l}M=2.50(0.00) \\
n=1\end{array}$ & - & - & $\begin{array}{l}M=1.25(0.69) \\
n=23\end{array}$ \\
\hline Total & $\begin{array}{l}M=1.39(0.82) \\
n=95\end{array}$ & $\begin{array}{l}M=1.25(0.68) \\
n=101\end{array}$ & $\begin{array}{l}M=2.50(0.00) \\
n=1\end{array}$ & $\begin{array}{l}M=1.00(0.00) \\
n=2\end{array}$ & $\begin{array}{l}M=1.25(0.00) \\
n=1\end{array}$ & $\begin{array}{l}M=1.32(0.75) \\
n=200\end{array}$ \\
\hline
\end{tabular}


Table 4

Means (SDs) and sample-sizes for Slut Shaming Victim Blaming as a Function of Race and Gender Responses

\begin{tabular}{|c|c|c|c|c|c|c|}
\hline Race & Male & Female & Transgender & Non Binary & Gender Fluid & Total \\
\hline White/European & $\mathrm{M}=3.30(1.28)$ & $\mathrm{M}=3.01(1.38)$ & - & $M=2.00(0.28)$ & $\mathrm{M}=2.40(0.00)$ & $\mathrm{M}=3.13(1.33)$ \\
\hline American & $n=79$ & $\mathrm{n}=79$ & & $\mathrm{n}=2$ & $\mathrm{n}=1$ & $n=161$ \\
\hline Black/African & $\mathrm{M}=3.17(0.72)$ & $M=2.60(1.34)$ & - & - & - & $M=2.85(1.12)$ \\
\hline American & $\mathrm{n}=7$ & $\mathrm{n}=7$ & & & & $n=16$ \\
\hline Other People of & $M=2.96(1.09)$ & $\mathrm{M}=3.12(1.68)$ & $M=5.00(0.00)$ & - & - & $M=3.13(1.46)$ \\
\hline Color & $n=9$ & $n=13$ & $n=1$ & & & $n=23$ \\
\hline \multirow[t]{2}{*}{ Total } & $M=3.26(1.22)$ & $M=2.99(1.41)$ & $M=5.00(0.00)$ & $M=2.00(0.28)$ & $M=2.40(0.00)$ & $M=3.11(1.32)$ \\
\hline & $n=95$ & $\mathrm{n}=101$ & $\mathrm{n}=1$ & $\mathrm{n}=2$ & $\mathrm{n}=1$ & $n=200$ \\
\hline
\end{tabular}

Table 5

Means (SDs) and sample-sizes for Slut Shaming Being the Victim as a Function of Race and Gender Responses

\begin{tabular}{lllllll}
\hline Race & Male & Female & Transgender & Non Binary & Gender Fluid & Total \\
\hline $\begin{array}{l}\text { White/Europ } \\
\text { ean }\end{array}$ & $\mathrm{M}=2.33(0.78)$ & $\mathrm{M}=2.23(0.71)$ & - & $\mathrm{M}=2.00(0.00)$ & $\mathrm{M}=3.00(0.00)$ & $\mathrm{n}=2.28(0.74)$ \\
American & $\mathrm{n}=79$ & $\mathrm{n}=79$ & & - & $\mathrm{n}=161$ \\
$\begin{array}{l}\text { Black/Africa } \\
\mathrm{n} \text { American }\end{array}$ & $\mathrm{M}=2.37(0.66)$ & $\mathrm{n}=7$ & $\mathrm{M}=2.33(0.79)$ & - & - & $\mathrm{M}=2.35(0.71)$ \\
$\begin{array}{l}\text { Other } \\
\text { People of }\end{array}$ & $\mathrm{M}=2.31(0.93)$ & $\mathrm{n}=9$ & $\mathrm{M}=2.15(0.30)$ & $\mathrm{M}=2.00(0.00)$ & - & $\mathrm{n}=16$ \\
$\begin{array}{l}\text { Color } \\
\text { Total }\end{array}$ & $\mathrm{M}=2.33(0.78)$ & $\mathrm{n}=13$ & $\mathrm{n}=1$ & $\mathrm{M}=2.21(0.61)$ \\
& $\mathrm{n}=95$ & $\mathrm{n}=101$ & $\mathrm{M}=2.00(0.00)$ & $\mathrm{M}=2.00(0.00)$ & $\mathrm{M}=3.00(0.00)$ & $\mathrm{n}=23$ \\
\end{tabular}


For the fifth research question (i.e., Will there be a positive correlation between how often women stigmatize others for sexual behavior and how often women experience sexual objectification?), I conducted correlation analyses (see Table 6). The correlation of women's behaviors $(M=1.26, S D=.68)$ and women's sexual objectifying experiences $(M=2.88, S D=$ .94) were highly significant $r(101)=.29, p=.003$. Sexual objectifying experiences were also significantly positively correlated with women's experiences being the victim $r(101)=.28$, $p=.004$ and also significantly correlated with women's sexual attitudes $r(101)=.30, p=.002$. Additional correlational analyses revealed that the correlation of women's beliefs and women's experiences being the victim $(M=2.23, S D=.68)$ was highly significant, $r(101)=.43, p \leq .001$. The correlation of women's behaviors $(M=1.25, S D=.68)$ and women's experiences being the victim was highly significant $r(101)=.91, p \leq .001$. Finally, the correlation of women's victim blaming $(M=2.99, S D=1.41)$ and women's experiences being the victim were highly significant $r(101)=.27, p=.007$.

For the sake of completeness, I conducted correlation analyses on men's responses -even though I did not have specific research question or hypotheses about men's responses. The correlation of men's beliefs and men's sexual objectifying experiences were highly significant $r(96)=.37, p \leq .001$. The correlation of men's behaviors and men's sexual objectifying experiences were highly significant $r(96)=.69, p \leq .001$. The correlation of men's victim blaming and men's sexual objectifying experiences were highly significant $r(96)=.36, p \leq .001$. Additional correlation analyses determined that the correlation between men's beliefs and men's experiences being the victim were highly significant $r(96)=.33, p=.001$. The correlation between men's behaviors and men's experiences being the victim were highly significant $r(96)=$ $.83, p \leq .001$. The correlation between men's victim blaming and men's experiences being the 
victim were significant $r(96)=.26, p=.012$. Finally, the correlation between men's sexual attitudes and men' experiences being the victim were significantly negatively correlated $r(96)=$ $.24, p=.029$. See Table 6 for the correlations for men and women's responses on the difference measures of the Slut Shaming Scale, the Interpersonal Sexual Objectification Scale, and the Brief Sexual Attitudes Scale.

Table 6

Correlations of Responses for Subscale of the Slut Shaming Scale

\begin{tabular}{|c|c|c|c|c|c|c|}
\hline Scales & 1 & 2 & 3 & 4 & 5 & 6 \\
\hline $\begin{array}{l}\text { 1. Slut Shaming } \\
\text { Beliefs }\end{array}$ & & $.427 * *$ & $.757 * *$ & $.332 * *$ & .029 & $.370 * *$ \\
\hline $\begin{array}{l}\text { 2. Slut Shaming } \\
\text { Behaviors }\end{array}$ & $.402 * *$ & & $.308 * *$ & $.829 * *$ & -.120 & $.688 * *$ \\
\hline $\begin{array}{l}\text { 3. Victim } \\
\text { Blaming }\end{array}$ & $.719 * *$ & $.226^{*}$ & & $.257 * *$ & .076 & $.359^{* *}$ \\
\hline $\begin{array}{l}\text { 4. Being the } \\
\text { Victim }\end{array}$ & $.426 * *$ & $.906 * *$ & $.267 * *$ & & $-.224^{*}$ & $.710 *$ \\
\hline $\begin{array}{l}\text { 5. Brief Sexual } \\
\text { Attitudes }\end{array}$ & -.165 & -.070 & -.089 & -.037 & & -.032 \\
\hline $\begin{array}{l}\text { 6. Sexual } \\
\text { Objectification }\end{array}$ & .119 & $.293 * *$ & .001 & $.284 * *$ & $.304 * *$ & \\
\hline M (Women) & 2.65 & 1.25 & 2.99 & 2.23 & 4.60 & 2.88 \\
\hline SD (Women) & 1.27 & 0.68 & 1.41 & 0.68 & 0.71 & 0.94 \\
\hline M (Men) & 3.00 & 1.38 & 3.26 & 2.33 & 4.70 & 2.23 \\
\hline SD (Men) & 1.20 & 0.82 & 1.22 & 0.78 & 0.72 & 0.83 \\
\hline
\end{tabular}

**- Correlation is significant at the 0.01 level (2 tailed)

*- Correlation is significant at the 0.05 level ( 2 tailed)

Note: Correlations for women are placed below the main diagonal whereas correlations for men are placed above the main diagonal. Sample size for men's responses were 96 and sample size for women's responses were 101.

For the sixth research question (i.e., Do women experience sexual objectifying actions aimed towards them more often than men?), I conducted an independent samples $t$-test on the 
responses from the interpersonal sexual objectification scale. The responses of the 96 male participants $(M=2.23, S D=.83)$ and the 101 female participants $(M=2.88, S D=.94)$ demonstrated highly significant differences in sexual objectifying experiences, $t(195)=-5.12, p \leq$ $.001, d=0.857$. 


\section{CHAPTER V: DISCUSSION}

We know from research that women are objectified and sexualized within our American society (Fasoli et al., 2017). We also know that people continue to believe that if women simply stopped dressing a certain way that victimization would stop (Ringrose \& Renold, 2012). This is important because data from the present research might suggest other relations. The primary goal of this study was to establish both reliability and validity for the newly developed Slut Shaming Scale. An internal consistency examination of reliability revealed that the measure has excellent reliability with Cronbach's alpha ranging between .88 and .97 . No items were excluded to increase Cronbach's Alpha. The exploratory factor analysis revealed the measure can be well represented with a single factor, supporting the factorial validity for the measure.

A second goal was to analyze several research questions that examined differences in experiences between men, women, and women of color. Interestingly, there were no significant differences between men's and women's experiences being the victim of slut shaming. This finding could be an area for follow up in future research with a larger sample size as this is a counterintuitive finding. Significant differences were found between men's and women's experiences of engaging in victim blaming, such that men responded to victim blaming questions in a way that indicated they believe victim blaming is more deserved when a man or woman dresses in a sexually revealing manner or when they share a nude photo of themselves. Correlation analyses supported a positive relation between men and women's behaviors and their sexually objectifying experiences, as well as men and women's behaviors and beliefs being positively correlated with their experiences being the victim. These results show that the more often men and women are sexually objectified or the victim of slut shaming, the more likely they are to hold beliefs and act in ways that support slut shaming and sexual objectification. No 
significant differences were found between White/European American women, Black/African American women, and other women of color for slut shaming beliefs, behaviors, victim blaming, and being the victim. Additionally, there was not a significant interaction between gender and race. It should be noted that the sample was not very diverse, meaning that the relatively small group of POC required that small categories be collapsed, which further limits the conclusiveness of these findings. It is possible that differences do exist in the way White women, and women of color experience slut shaming, or even that differences exist between gender responses across race, but this study did not have enough power to expose those differences.

An examination of the correlations between men's and women's responses on the Slut Shaming Scale subscales (i.e., beliefs, behaviors, victim blaming, and being the victim), the Interpersonal Sexual Objectification Scale, and the Brief Sexual Attitudes Scale revealed consistency in the correlations across men's and women's responses. This similarity indicates that there is a significant positive correlation between slut shaming beliefs and how often someone is the victim of slut shaming. Additionally, slut-shaming behaviors and slut shaming experiences being the victim are significantly positively correlated with men's and women's experiences of sexual objectification. Because this finding is correlational, we cannot say whether or not men and women engage in slut shaming because of their experiences or if one develops attitudes and then engages in behaviors, but a relation appears to exist.

I found significant differences between the way men and women experience sexual objectification. Women report experiencing sexual objectification significantly more often than men. These results are consistent with results from previous studies (Fasoli et al., 2017). It is interesting to consider that even though research shows sexual objectification occurs more often 
toward women, that both men and women have experiences that significantly impact their beliefs and behaviors.

\section{Limitations}

Several limitations of this study should be noted. The first limitation is that the sample was not very diverse. The sample was predominately White/European American, and the majority identified as male and female. Several analyses did not reveal significant differences, possibly because differences did not exist, or because the sample was not diverse enough to identify those differences. Additionally, the age of participants could also serve as a limitation. The minimum participant age was 18 with a maximum of 72 . It could be possible some of the participants do not understand or experience slut shaming due to generational understanding and comprehension of slut shaming beliefs, behaviors, victim blaming, and being the victim of slut shaming.

Another limitation is that the study was conducted via online survey. Though I tried to combat inattention through multiple attention check questions, it is possible that some participants were attentive enough to answer the attention check questions properly but also not enough to read through the questions thoroughly. There was not enough information to exclude any participants for this reason alone, but it should be noted as a possible limitation to the study.

Another limitation could be men's expectancy effects on their responses. It is possible that men were more sensitive to the hypothesis that they would engage in more slut shaming due to the clear wording of these questions asking about the differences between men's and women's behaviors. If men expected this to be the hypothesis based on the wording of the slut shaming items, they may have under-reported these behaviors. 


\section{Implications}

The primary goal of this study was to create a measure for slut shaming. The Slut Shaming Scale I created exhibited strong reliable evidence and strong evidence of factorial validity, with no items being excluded from the original measure. This implication is extremely important because there were no published measures of slut shaming in the extant literature. This scale can be implemented in a variety of settings for research in schools, colleges, and work places. For example, if the scale were to be used in a school setting that is dealing with significant gendered bullying, it could be used to measure slut-shaming behaviors and determine if slut shaming is part of the bullying behaviors. It could also be used within a school setting to measure slut-shaming beliefs, which may provide information about the school climate. If the scale were to be used in a work setting, again, it could help inform workplaces about the work climate and with respect to slut shaming attitudes and related sexual harassment issues. It is important to have a reliable and valid measure in research in order to be able to make data-based decisions in terms of intervention regarding results from the measure. Having a reliable and valid scale ensures researchers are measuring what is intended to be measured consistently.

\section{Future Research Directions}

This is the first time that the Slut Shaming Scale has been used and although our data support the reliability and validity of the scale, our study has limitations in regards to diversity. First and foremost, future research should work to replicate the reliability findings and use additional validity models. Future research should also aim to establish validity in diverse samples.

Due to the frequency of objectification, we need to continue to develop research finding out more information about who is participating in these objectifying and shaming behaviors so 
we can begin to address interventions to stop the behavior. Now that we have established validity and reliability for this measure, limitations should be taken into consideration and additional studies should be conducted with an aim to establish validly and reliability with a more diverse sample. Doing this would allow researchers to examine some of differences between White men and women, and men and women of color. Additional limitations, such as the variation in participant age, should also be considered in creating a future research study to determine if differences exist in slut shaming experiences depending on generation. Finally, researchers could also aim to examine the relation between sexual orientation or gender identity and slut shaming beliefs, behaviors, victim blaming, and being the victim of slut shaming.

Correlations indicate important relations between different elements of slut-shaming, sexual objectification, and sexual attitudes between men and women. Further, these relations could guide future research questions, such as examining why some correlations were significant across men but not women.

\section{Conclusion}

This study was able to find evidence to support our first and second hypothesis, regarding the reliability and validity of the Slut Shaming Scale. The results of this study provide the beginning of evidence to support the Slut Shaming Scale as a reliable and valid measure. Sound research cannot be conducted without a measure with established reliability and validity evidence. It is important for researchers to use this measure to allow for opportunity to compare findings across studies.

Though this study did not find significant evidence regarding the differences in experiences and attitudes of slut shaming in White men and women compared to men and women of color, it important to note that this study did not have a sample that was large in order 
to measure those differences. This study did find evidence regarding correlations between different elements of slut shaming (beliefs, behaviors, victim blaming, and being the victim) in comparison to sexual objectification and sexual attitudes in men and women. 


\section{REFERENCES}

Almazan, V. A., \& Bain, S. F. (2015). College students' perceptions of slut-shaming discourse on campus. Research in Higher Education, 28, 1-9.

Baumeister, R., \& Twenge, J. (2002). Cultural Suppression of Female Sexuality. Review of General Psychology, 6(2), 166-203.

Crawford, M., \& Popp, D. (2003). Sexual double standards: A review and methodological critique of two decades of research. Journal of Sex Research, 40(1), 13-26.

Dockterman, E. (2014, March 25). When Enforcing School Dress Codes Turns Into Slut Shaming. Retrieved March 23, 2018, from http://time.com/36997/when-enforcingschool-dress-codes-turns-into-slut-shaming/

Fasoli, F., Durante, F., Mari, S., Zogmaister, C., \& Volpato, C. (2017). Shades of sexualization: When sexualization becomes sexual objectification. Springer Science Business Media, $78,338-351$.

Hamilton, L., \& Armstrong, E. (2009). Gendered sexuality in young adulthood. Gender and Society,23(5), 589-616.

Hendrick, C., Hendrick, S., \& Reich, D. (2006). The brief sexual attitudes scale. Journal of Sex Research,43(1), 76-86.

Kohli, S. (2016, February 22). The problem with slut shaming in schools. Retrieved March 21, 2018, from http://www.latimes.com/local/education/lausd/la-me-edu-slut-shaming20160218-story.html

Kozee, H. B., Tylka, T. L., Augustus-Harvath, C. L., \& Denchik, A. (2007). Development and psychometric evaluation of the interpersonal sexual objectification scale. Psychology of Women Quarterly,31, 175-189. 
Mikorski, R., \& Szymanski, D. (2016). Masculine norms, peer group, pornography, facebook, and men's sexual objectification of women. Psychology of Men \& Masculinity, 18(4), $257-267$.

Mishna, F., Schwan, K. J., Birze, A., Van Wert, M., Lacombe-Duncan, A., McInroy, L., \& AttarSchwartz, S. (2018). Gendered and sexualized bullying and cyber bullying: Spotlighting girls and making boys invisible. Youth \& Society, 1-24.

Pickel, K., \& Gentry, R. (2016). Slut shaming in a school bullying case: Evaluators ignore Level of Harm When the Victim Self-Presents as Sexually Available. Sex Roles, 76(1-2), 89-98.

Rose, A. (n.d.). The Amber Rose Foundation. Retrieved September 28, 2018, from http://www.theamberrose.org/

Ringrose, J., \& Renold, E. (2012). Slut-shaming, girl power and 'sexualisation': Thinking through the politics of the international SlutWalks with teen girls. Gender and Education,3, 333-343.

SlutWalk- The Mission (AMBER ROSE FOUNDATION). (n.d.). Retrieved April 16, 2018, from http://amberroseslutwalk.com/our-story/

Soller, B., \& Haynie, D. (2017). Variation in Sexual Double Standards across Schools: How Do They Matter for Adolescent Sexual Behavior? Gender and the Status of Women,60(4), $702-721$.

Summit, A. K., Kalmuss, D., DeAtley, J., \& Levack, A. (2016). Unraveling the slut narrative: Gender constraints on adolescent girls' sexual decision-making. American Journal of Sexuality Education,11(2), 113-128. http://dx.doi.org/10.1080/15546128.2016.1168755

Vaillancourt, T., \& Sharma, A. (2011). Intolerance of Sexy Peers: Intrasexual Competition Among Women. AGGRESSIVE BEHAVIOR,37, 569-577. 
Watson, L., Marszalek, J., Dispenza, F., \& Davids, C. (2015). Understanding the relationships among white and african american women's sexual objectification experiences, physical safety anxiety, and psychological distress. Springer Science Business Media New York ,72, 91-104. 


\section{APPENDIX: SCALES}

\section{Slut Shaming Scale}

\section{PERSONAL BELIEFS}

Please rate your level of agreement with the following statements.

1 (strongly disagree), 2 (disagree), 3 (slightly disagree), 4 (neutral), 5 (slightly agree), 6 (agree), (strongly agree)

I think women are "sluts" for dressing is revealing ways (e.g., short shorts/skirts, low cut blouses or tank tops, belly shirts).

I think men are "sluts" for dressing in revealing ways (e.g., wearing V-neck shirts, no shirts at all, or wearing speedos instead of swim trunks).

I consider women "sluts" based on their use of contraceptives (e.g., birth control, condoms).

I consider men "sluts" based on their use of contraceptives (e.g., condoms).

I consider women "sluts" based on the number of sexual partners they have had (e.g., more than 5 sexual partners).

I consider men "sluts" based on the number of sexual partners they have had (e.g., more than 5 sexual partners).

I consider women "sluts" for engaging in premarital sex.

I consider men "sluts" for engaging in premarital sex.

I consider women who engage in stripping to be "sluts".

I consider men who engage in stripping to be "sluts".

I consider women who engage in prostitution to be "sluts".

I consider men who engage in prostitution to be "sluts".

If a woman has sexual practices that are different from my own (e.g., masturbation, premarital sex, experimentation with same-sex partners, experimentation with dominance and submission), I would consider her to be a "slut".

If a man has sexual practices that are different from my own (e.g., masturbation, premarital sex, experimentation with same-sex partners, experimentation with dominance and submission), I would consider him to be a "slut". 


\section{ACTUAL BEHAVIORS}

Please rate the average amount of times you experience being called a slut under the following conditions. $0,1-4,5-9,10-14,15-19,20-24,25$ or more

On average, how many times within a month do you call a woman a "slut" (e.g., to friends, gossip) behind her back, based on her sexual practices?

On average, how many times within a month do you call a man a "slut" (e.g., to friends, gossip) behind his back, based on his sexual practices?

On average, how many times within a month have you directly called a woman a "slut" (to their face, online) based on her sexual practices?

On average, how many times within a month have you directly called a man a "slut" (to their face, online) based on his sexual practices?

\section{VICTIM BLAMING}

Please rate your level of agreement with the following statements.

1 (strongly disagree), 2 (disagree), 3 (slightly disagree), 4 (neutral), 5 (slightly agree), 6 (agree), (strongly agree)

I feel that a woman who dresses in a revealing or provocative way is at least partially responsible if she is sexually harassed or sexually assaulted.

I feel that a man who dresses in a revealing or provocative way is at least partially responsible if he is sexually harassed or sexually assaulted.

I feel that if a woman takes a nude photo of herself, only she is to blame if that photo gets distributed to people other than the intended recipient.

I feel that if a man takes a nude photo of himself, only he is to blame if that photo gets distributed to people other than the intended recipient.

\section{BEING THE VICTIM OF SLUT SHAMING}

Please rate the average amount of times you experience being called a slut under the following conditions. $0,1-4,5-9,10-14,15-19,20-24,25$ or more

On average, how many times within the past month have you been called a "slut" in person because of your sexual history? 
On average, how many times within the last month have you been called a "slut" online because of your sexual history?

On average, how many times within the past month have you been called a "slut" in person because someone made assumptions about your sexual experience or sexual history?

On average, how many times within the past month have you been called a "slut" online because someone made assumptions about your sexual experience or sexual history? 


\section{Interpersonal Sexual Objectification Scale}

**Items are rated along a 6-point scale ranging from 1 (the event never happened) to 6 (the event happened almost all the time).

\section{BODY EVALUATION}

1. How often have you been whistled at while walking down a street?

2. How often have you noticed someone staring at your breasts when you are talking to them?

3. How often have you felt like or known that someone was evaluating your physical appearance?

4. How often have you felt that someone was staring at your body?

5 . How often have you noticed someone leering at your body?

6. How often have you heard a rude, sexual remark made about your body?

7. How often have you been honked at when you were walking down the street?

8. How often have you seen someone stare at one or more of your body parts?

9. How often have you overheard inappropriate sexual comments made about your body?

10. How often have you noticed that someone was not listening to what you were saying, but instead gazing at your body or a body part?

11. How often have you heard someone make sexual comments or innuendos when noticing your body?

\section{UNWANTED EXPLICT SEXUAL ADVANCES}

12. How often have you been touched or fondled against your will?

13. How often have you experienced sexual harassment (on the job, in school, etc.)?

14. How often has someone grabbed or pinched one of your private body areas against your will?

15. How often has someone made a degrading sexual gesture towards you? 
Permissiveness

\section{Brief Sexual Attitudes Scale}

I do not need to be committed to a person to have sex with him/her.

Casual sex is acceptable.

I would like to have sex with many partners.

One-night stands are sometimes enjoyable.

It is okay to have ongoing sexual relationships with more than one person at a time.

Sex as a simple exchange of favors is okay if both people agree to it.

The best sex is with no strings attached.

Life would have fewer problems if people could have sex more freely.

It is possible to enjoy sex with a person and not like that person very much.

It is okay for sex to be just good physical release.

\section{Birth Control}

Birth control is part of responsible sexuality.

A woman should share responsibility for birth control.

A man should share responsibility for birth control.

Communion

Sex is the closest form of communication between two people.

A sexual encounter between two people deeply in love is the ultimate human interaction.

At its best, sex seems to be the merging of two souls.

Sex is a very important part of life.

Sex is usually an intensive, almost overwhelming experience.

Instrumentality

Sex is best when you let yourself go and focus on your own pleasure.

Sex is primarily the taking of pleasure from another person.

The main purpose of sex is to enjoy oneself.

Sex is primarily physical.

Sex is primarily a bodily function, like eating 